\title{
THE CHARACTERISTICS OF PROBIOTIC DRINK BASED ON MORINGA LEAVES JUICE
}

\author{
[Karakteristik Minuman Probiotik Berbasis Jus Daun Kelor]
}

\section{Dewi Desnilasari, Wawan Agustina, Devry Pramesti Putri, Ade Chandra Iwansyah, Woro Setiaboma, Enny Sholichah, and Ainia Herminiati}

Research Center for Appropriate Technology, Indonesian Institute of Sciences (LIPI), Subang

Received May $5^{\text {th }} 2020 /$ Accepted February $27^{\text {th }} 2021$

\begin{abstract}
Moringa (Moringa oleifera) is rich in minerals, vitamins, and other essential phytochemicals. This research aimed to evaluate the effect of addition skim milk powder to the characteristics of probiotic drinks based on moringa leaves juices. The probiotic drink was fermented by Lactobacillus casei FNCC 00090 with different levels of skim milk powder $(0,3,5$, and $7 \%)$. The results showed that supplementation skims milk powders significantly affected the color of the probiotic product. The higher level of skim milk powders, the lighter, greener, and more yellow in the color $(P<0.05)$. The higher concentration of skim milk, the higher of $\mathrm{pH}$ and lactic acid content resulted. The number of probiotics among the treatment was not significantly different. The addition of $7 \%$ skims milk powder produced the highest protein content, antibacterial activity, phenolic content, and antioxidant activity. This product has a protein content of $2.65 \%$, antibacterial activity: $14.50 \pm 1.80 \mathrm{~mm}$ (zone inhibition of $E$. coli) and $35.33 \pm 4.16 \mathrm{~mm}$ (zone inhibition of $S$. aureus), phenolic content of $0.2410 \pm 0.0054 \mathrm{mg}$ equivalent gallic acid $/ \mathrm{mL}$ sample, and antioxidant activity of $75.18 \pm 1.45 \%$. The probiotics drink based on moringa leaves juices has the potential to be developed as a functional drink.
\end{abstract}

Keywords: antibacterial, antioxidant, moringa, probiotic

\begin{abstract}
ABSTRAK
Daun kelor (Moringa oleifera) kaya akan mineral, vitamin dan senyawa fitokimia penting. Penelitian ini bertujuan mengevaluasi pengaruh konsentrasi bubuk susu skim terhadap karakterisitik minuman probiotik berbasis jus daun kelor. Minuman probiotik difermentasi oleh Lactobacillus casei FNCC 00090 pada konsentrasi bubuk susu skim (0,3,5, dan 7\%). Konsentrasi bubuk susu skim pada penelitian ini berpengaruh nyata terhadap warna produk. Semakin bertambahnya bubuk susu skim, semakin cerah, hijau dan kekuningan warna minuman probiotik $(P<0,05)$. Minuman probiotik dengan penambahan $7 \%$ bubuk susu skim memiliki kadar protein yang paling tinggi (2,65\%). Semakin bertambahnya susu skim, semakin tinggi $\mathrm{pH}$ dan kandungan asam laktatnya. Jumlah probiotik tidak berbeda signifikan pada berbagai perlakuan. Penambahan 7\% bubuk susu skim menghasilkan kandungan protein, aktivitas antibakteri, kandungan fenolik dan aktivitas antioksidan tertinggi. Produk yang terbaik memiliki kandungan protein se-

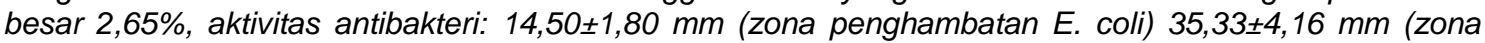
penghambatan S. aureus), kandungan fenolik 0,2410 $\pm 0,0054 \mathrm{mg}$ equivalent asam galat $/ \mathrm{mL}$ sampel dan aktivitas antioksidan $75,18 \pm 1,45 \%$. Minuman probiotik dari daun kelor potensial untuk dikembangkan sebagai minuman fungsional.
\end{abstract}

Kata kunci: antibakteri, antioksidan, kelor, probiotik

\section{INTRODUCTION}

Moringa (Moringa oleifera) is a nutritious plant that is a source of essential phytochemicals in its all part of their plant, and it belongs to the family of

The manuscript has been presented in The $16^{\text {th }}$ Asean Food Conference 2019, October $15^{\text {th }}-18^{\text {th }} 2019$, Bali-Indonesia ${ }^{*}$ Corresponding Author: E-mail: dewi.desnilasari@gmail.com
Moringaceae (Gopalakrishnan et al., 2016). Moringa tree is known as miracle trees because of its health benefits, and most parts of the tree are widely consumed as traditional food (Vanajakshi et al., 2015). Leaves, flowers, pods, and fruits of moringa are rich in nutritional content such as proteins, lipids, minerals, and fiber (Melo et al., 2013; Mawouma et al., 2017). Besides it, their pods, flowers, and leaves contain abundant bioactive compounds such as $\beta$ - 
carotene, tocopherol, vitamin $\mathrm{C}$, phenolic compounds, and some essential amino acids (Ferreira et al., 2008; Martinez et al., 2017). According to Moyo et al. (2011), the chemical content of moringa dried leaves is protein $30.29 \%$, fat $6.5 \%$, moisture $9.53 \%$, ash $7.64 \%$, fiber $11.40 \%$, tannin $3.12 \mathrm{mg} / \mathrm{g}$, Vitamine E $77 \mathrm{mg} / \mathrm{kg}$, beta carotene $18.50 \mathrm{mg} / 100 \mathrm{~g}$ and $\mathrm{mi}-$ nerals.

The nutrition and bioactive compound of moringa could be utilized as a healthy food source for human beings. In Indonesia and Philippine, moringa traditionally has been processed as traditional cuisine (Aminah et al., 2015). In East Indonesia that is in Sumba Barat Daya, Nusa Tenggara Timur, moringa leaves have been processed to become various products such as tea, snack, Moringa olifera meatballs, and pudding.

Other research has been done utilized moringa as a beverage based on its leaves, such as herbal tea moringa (Lalas et al., 2017), cereal grain beverage with moringa leaves (Olusanya et al., 2019) and also become a probiotic drink based on its leaves (Vanajakshi et al., 2015). Nowadays, the probiotic drink has become popular cause it has excellent health benefits and high nutritional value (Zhang et al., 2019). The living microbe in the probiotic drink confer a health benefit on the host (Amara and Shibl, 2015; He and Shi, 2017). A probiotic drink based on moringa leaves and beetroot juice showed good potential as antibacterial for Listeria monocytogenes, Bacillus cereus, Staphylococcus aureus, and Escherichia coli. Moreover, it has antioxidant activity with phenolic content of 5 $\mathrm{mg} / \mathrm{mL}$ and high mineral content such as calcium and iron (Vanajakshi et al., 2015). There is limited information about probiotic drinks based on moringa leaves juice its self in the highest concentration. The research was conducted to evaluate probiotic drink characteristics based on moringa leaves added with various skim milk powder concentrations.

\section{MATERIALS AND METHODS}

\section{Materials}

Moringa leaves were collected from Subang, West Java, Honey (MMN Randu Honey), sucrose, carboxyl methylcellulose (CMC), mineral water, and skim milk powder local market. Lactobacillus casei FNCC 00090, Escherichia coli, and Staphylococcus aureus were purchased from Pusat Studi Pangan dan Gizi (PSPG) Universitas Gadjah Mada. The reagents for analysis were buffer peptone water (BPW) (Merck, Germany), de man rogosa sharpe broth and agar/MRSB/MRSA (Merck, Germany), Nutrient Agar (Merck, Germany), $\mathrm{NaOH}$ (Merck, Germany), and 2,2-diphenyl-1-picrylhydrazyl (DPPH) (Sigma, Germany).

\section{Research design and data analysis}

This research was conducted used a completely randomized design with one factor. The factor was four levels of supplementation skim milk. The concentrations added as tested were $0,3,5$, and $7 \%$, then repeated three times. The data was analyzed using SPPS 16.0 by one-way ANOVA. A probability value of $P<0.05$ was considered statistically significant.

\section{Preparation of juice (Agustina et al., 2019)}

Fresh moringa leaves were washed, put in a blender cup, added mineral water, and mixed homogeneously. The ratio of moringa and mineral water was $1(\mathrm{~kg}): 5(\mathrm{~L})$. The puree of moringa leaves was filtered using a cloth filter and stainless wire. The mixing and filtering steps were repeated until they were fully extracted. moringa juice was prepared by adding moringa extract with $7.5 \%$ sucrose, $2.5 \%$ honey, and $200 \mathrm{ppm} \mathrm{CMC}$. The next step was to cook moringa juice until boiling.

\section{Preparation of probiotic starter (Desnilasari and Kumalasari, 2017)}

L. casei were inoculated in $50 \mathrm{~mL}$ of MRSB and incubated at $37^{\circ} \mathrm{C}$ for 24 hours. Furthermore, the media that consist of $5 \%$ skimmed milk was inoculated with $L$. casei and incubated for 24 hours at $37^{\circ} \mathrm{C}$. The lactic acid bacteria starter is ready to inoculate in the juice.

\section{Preparation of the probiotic drink (Agustina et al., 2019)}

Moringa leaves juice was divided into four treatments (addition with 0, 3, 5, and 7\% skim milk powder) with triplicated. All of the samples were pasteurized in a water bath for 15 minutes at $75^{\circ} \mathrm{C}$. The mixed juices were tempering until temperature $\pm 37^{\circ} \mathrm{C}$ before inoculating it with $5 \% \mathrm{~L}$. casei starter, and then, it was incubated at $37^{\circ} \mathrm{C}$ for 24 hours.

\section{Physicochemical analysis (AOAC, 2004)}

The probiotic product's color was determined using a $3 \mathrm{NH}$ colorimeter to obtain the $\mathrm{L}, \mathrm{a}$, and $\mathrm{b}$ scores (Desnilasari and Kumalasari, 2017). The pH of the probiotic product was measured using a $\mathrm{pH}$ meter (SI Analytics). The total free acid value was determined with the volumetric method using $\mathrm{NaOH}$ $0.1 \mathrm{M}$. The protein content was analyzed using the Dumas combustion method using DuMaster (Buchi D-480, Switzerland).

\section{Microbiological analysis (Desnilasari and Kumalasari, 2017) \\ The probiotic drink was evaluated for total lactic acid bacteria (L. casel) by serial dilutions. Briefly, 10 $\mathrm{mL}$ of the product was mixed in $90 \mathrm{~mL}$ of BPW and homogenized using a vortex. The serial dilutions}


were prepared, and the pour plate method was used to carry out the viable bacteria count.

\section{Antibacterial activity measurement (Balouiri et al., 2016)}

The antibacterial analysis was determined using the diffusion agar plate method, according to Balouiri et al. (2016), with modification in the media by using nutrient agar. Nutrient agar was inoculated with $E$. coli or $S$. aureus. After that, the paper disc (6 $\mathrm{mm}$ ) contains the probiotic product was placed on the agar surface. Then, it was incubated at $37^{\circ} \mathrm{C}$ for 24 hours. Lastly, the inhibition zone has measured the diameter of the clear zone around the paper disk.

\section{Antioxidant properties analysis (Sompong et al., 2011)}

Antioxidant activity was determined using DPPH methods as described by Sompong et al. (2011). The probiotic drink was pipetted $0.3 \mathrm{~mL}$, and then added $1.5 \mathrm{~mL}$ DPPH $0.24 \mathrm{mM}$ and $2 \mathrm{~mL}$ ethanol. The solution was mix used vortex and incubated in the dark chamber for 40 minutes at room temperature. The absorbance of the solution was read at $515 \mathrm{~nm}$ using Spectrophotometer UV-Vis (Shimadzu 1900, Japan). The solution contained DPPH and ethanol was used as a control solution included in the calculation formula. Antioxidant activity was measured with this equation:

\section{Scavenging Ability= \\ $\left(\frac{\text { absorbance control-absorbance sample }}{\text { absorbance control }}\right) \times 100 \%$}

Total phenolic content was determined by spectrophotometry method. The sample with $200 \mu \mathrm{L}$ volume was reacted with $1.5 \mathrm{~mL}$ of $10 \%$ FolinCiocalteau reagent and $1.5 \mathrm{~mL}$ of $\mathrm{Na}_{2} \mathrm{CO}_{3}$ made from $75 \mathrm{~g} / \mathrm{L}$. Furthermore, this solution was incubated for 2 hours in a dark room. The absorbance of the solution was measured at $\lambda 725 \mathrm{~nm}$. Total phenolic concentrations are based on linear regression of gallic acid standard curves (Shao et al., 2014).

\section{RESULTS AND DISCUSSION}

\section{Physicochemical characteristics}

The $L$ value represents the lightness parameter (black $=0$, white $=100)$. A of value represents reflected light which produces a chromatic red-green mixture (redness $=+a$ (positive) from $0-100$, greenness $=-a$ (negative) from $0-(-80)) . B$ of value represents a blue-yellow mixture (yellowness $=+b$ (positive) from $0-70$, blue $=-b$ (negative) value from $0-(-$
70)). The color of probiotic drink based moringa leaves was showed in Table 1. According to Table 1, the higher concentration of skim milk powder, the more increased $L$ and $b$ value of the product, and the more decreased the value. Product without skim milk had the lowest lightness, but additional skim milk affected the fermented drink's lightness.

Moreover, skim milk added to the fermented product would stabilize the dominant color of the product. The value of a represents redness to greenness. Additional skim milk caused to decreased the a value so that the probiotic drink was green. Furthermore, the higher concentration of skim milk would affect the product's color to become more yellow. Pasteurized skim milk has a dominant color, yellow (Bruzantin et al., 2016).

Table 1. The color value of probiotic drink based Moringa oleifera

\begin{tabular}{cccc}
\hline $\begin{array}{c}\text { Variation of } \\
\text { Skim Milk (\%) }\end{array}$ & L Value & $\mathrm{a}^{*}$ Value & $\mathrm{b}^{*}$ Value \\
\hline 0 & $28.81^{\mathrm{a}}$ & $1.82^{\mathrm{d}}$ & $7.40^{\mathrm{a}}$ \\
3 & $31.46^{\mathrm{b}}$ & $1.24^{\mathrm{c}}$ & $10.72^{\mathrm{b}}$ \\
5 & $34.20^{\mathrm{c}}$ & $0.73^{\mathrm{b}}$ & $13.33^{\mathrm{c}}$ \\
7 & $35.03^{\mathrm{d}}$ & $0.26^{\mathrm{a}}$ & $14.04^{\mathrm{d}}$ \\
\hline
\end{tabular}

Note: Different letter after value showed significantly in $P<0.05$

Lactic acid content was determined based on the titration method. The result showed in Table 2 indicated that skim milk powder could increase the total lactic acid in the probiotic drink. Product without skim milk also has a high total of titrated acid. It indicated that without skim milk, the fermentation process has also occurred. Based on BSN (2009), lactic acid for yogurt is between $0.5-2.0 \%$, but according to the SNI for fermented milk, the lactic acid for fermented milk is $0.2-0.9 \%$ (BSN, 2009). According to Gezginc et al. (2015), the expected level of lactic acid from yogurt is around $0.95 \%$, and the product has a sharp and acidic taste. Thus, the value of acid as lactic acid from this research is higher than expectations and existing standards. In other research, the value of lactic acid from probiotic drinks made from Centella asiatica leaves ranges from 0.40-1.20 with skim milk powder concentration as much as $0-9 \%$ (Agustina et al., 2019). The high total of titrated acid is possible because of the high content of ascorbic acid (vitamin C) from moringa leaves. The content of vitamin $C$ in fresh moringa leaves is estimated to range between 2-4 times greater than lemon and mosambi (Sankhyan et al., 2013).

The increase of lactic acid is not in line with the $\mathrm{pH}$. The $\mathrm{pH}$ of probiotic drink tends to increase with a higher concentration of skim milk. A good $\mathrm{pH}$ value for probiotic drinks (yogurt) according to Food Standards Australia New Zealand Food Standard (2007) has a maximum value of 4.5. According to Gezginc 
et al. (2015), several types of mild yogurts are produced at a $\mathrm{pH}$ of around 4.6. Thus, the $\mathrm{pH}$ value created is included in a suitable category (Gezginc et al., 2015). The $\mathrm{pH}$ value of probiotic drink based moringa did not differ from the $\mathrm{pH}$ value of some other probiotic beverages such as those produced from lay durian juice (Durio kutejensis), which is around 4.45 (Yuliana et al., 2017), yogurt with pineapple juice ranging from 4.15-4.18 (Insyiroh et al., 2014).

Table 2. Total acid, pH, and protein contents of Moringa oleifera probiotic drink

\begin{tabular}{cccc}
\hline $\begin{array}{c}\text { Variation of } \\
\text { Skim Milk } \\
(\%)\end{array}$ & $\begin{array}{c}\text { Acid } \\
\text { Titrated }(\%)\end{array}$ & $\mathrm{pH}$ & $\begin{array}{c}\text { Protein } \\
(\%)\end{array}$ \\
\hline 0 & $3.05 \pm 0.14^{\mathrm{a}}$ & $3.83 \pm 0.01^{\mathrm{a}}$ & $0.72 \pm 0.07^{\mathrm{a}}$ \\
3 & $4.80 \pm 0.53^{\mathrm{b}}$ & $4.01 \pm 0.08^{\mathrm{b}}$ & $1.64 \pm 0.01^{\mathrm{b}}$ \\
5 & $5.85 \pm 0.21^{\mathrm{c}}$ & $4.09 \pm 0.01^{\mathrm{b}}$ & $2.06 \pm 0.02^{\mathrm{c}}$ \\
7 & $5.29 \pm 0.10 \mathrm{~b}^{\mathrm{c}}$ & $4.49 \pm 0.08^{\mathrm{c}}$ & $2.65 \pm 0.07^{\mathrm{d}}$ \\
\hline
\end{tabular}

Note: Different letter after value showed significantly in $P<0.05$

The protein content of probiotic drink based moringa leaves increased significantly with the increase of skim milk concentration. This result in line with the research by Pato et al. (2017). After adding the skim milk, this value already fulfilled the SNI (BSN, 2009) for fermentation milk beverage, which is a minimum protein content is $1 \%$. In other probiotic drinks, probiotic drinks from antanan (Centella asiatica) with the addition of $0-9 \%$ skimmed milk powder have a protein content ranging from 3.71$8.59 \%$ (Agustina et al., 2019). Probiotic drinks from cow's milk with $5 \%$ moringa leaves extract produced the highest protein content, which was $0.87 \%$ (Rahmawati, 2015).

\section{Microbiological characteristics}

Lactic acid bacteria of the probiotic drink showed in Table 3. Lactic acid bacteria did not significantly differ among the treatments. This data showed that the lactic acid bacteria all treatment has $10^{8} \mathrm{CFU} / \mathrm{mL}$ amount. Based on the data above, it is known that the viability of lactic acid bacteria in the whole sample of moringa leaves probiotic drinks is following SNI fermented milk beverage, the viability of lactic acid bacteria must be above $10^{6}$ colonies $/ g$ or greater than 6 logs CFU/mL. The highest viability sample was a sample with $5 \%$ skims milk powder around $8.82 \mathrm{CFU} / \mathrm{mL}$. In other probiotic-based drinks such as lay durian, the best selection is a mixed culture with $L$. plantarum and $L$. acidophilus having live $L A B$ cells as much as 9.33 log CFU/mL (Yuliana et al., 2017). Research by Pato et al. (2017), addition $7,5 \%$ skims milk powder result in 9.43 log CFU/ $\mathrm{mL}$.

Table 3 also showed that probiotic drink based Moringa oleifera has antibacterial activity to $S$. aureus and E. coli. Increasing the concentration of skim milk in the product did not significantly increase the inhibition zone for $E$. coli. The inhibition zone $S$.aureus higher than E. coli. E. coli was gramnegative bacteria, and $S$. aureus was gram-positive bacteria. This antibacterial activity's ability increases in both types of bacteria with the increasing amount of skim milk added. Inhibition of $S$. aureus grampositive bacteria was better than gram-negative $E$. coli bacteria. It is in line with the antimicrobial activity of probiotic drinks from Antanan and probiotic drinks from date palm juice, which can inhibit the growth of $S$. aureus and $E$. coli, the inhibition of $S$. aureus is better when compared to inhibition of $E$. coli (Agustina et al., 2019; Khotimah and Kusnadi, 2014). Gram (+) bacteria were more sensitive to chemical compounds than a gram (-). It is probably caused by differences in the composition and structure of their cell walls. The cell walls of gram $(+)$ bacteria is relatively more straightforward than gram $(-)$ bacteria. Cell walls of gram (+) bacteria were single layer with low lipid (1-4\%), while the gram (-) bacterial consists of three layers with a lipid composition of about $11-12 \%$. Three layers, namely the outer lipoprotein, the middle lipopolysaccharide, and the inner was peptidoglycan. Therefore gram (+) bacteria cell wall is more easily penetrated by active compounds derived from plant extracts (Agustina et al., 2019).

Table 3. Viability of probiotic and antibacterial activity of Moringa oleifera probiotic drink

\begin{tabular}{|c|c|c|c|}
\hline \multirow{2}{*}{$\begin{array}{l}\text { Variation } \\
\text { of Skim } \\
\text { Milk (\%) }\end{array}$} & \multirow{2}{*}{$\begin{array}{c}\text { Lactic Acid } \\
\text { Bacteria } \\
\text { Content } \\
\text { (log CFU/mL) }\end{array}$} & \multicolumn{2}{|c|}{ Zone of Inhibition (mm) } \\
\hline & & E.coli & $S$. \\
\hline 0 & $8.60 \pm 0.03^{a}$ & $11.67 \pm 2.08^{a}$ & $28.33 \pm 2.89^{a}$ \\
\hline 3 & $8.73 \pm 0.19^{\mathrm{a}}$ & $12.33 \pm 1.53^{\mathrm{a}}$ & $29.33 \pm 3.79^{\mathrm{ab}}$ \\
\hline 5 & $8.82 \pm 0.09^{\mathrm{a}}$ & $14.33 \pm 2.08^{a}$ & $32.00 \pm 2.00^{\mathrm{ab}}$ \\
\hline 7 & $8.71 \pm 0.11^{\mathrm{a}}$ & $14.50 \pm 1.80^{\mathrm{a}}$ & $35.33 \pm 4.16^{\mathrm{C}}$ \\
\hline
\end{tabular}

Note: Different letter after value showed significantly in $P<0.05$

These probiotic drinks ability to inhibit bacterial growth is possible because of phenolic compounds in the product. The number of hydroxyls $(\mathrm{OH})$ functional groups in the phenol group is toxic to microorganisms. The higher the phenol compound was oxidized, the stronger the toxicity and inhibition of microorganism growth. The phenols'content at high concentrations can penetrate and disrupt bacterial cell walls and precipitate proteins in bacterial cells. Also, phenols can cause inactivation of cellular enzymes, coagulation of proteins, change the permeability of bacterial membranes, and finally, membrane cells undergo lysis (die). Whereas at lower concentrations, phenols can form complex bonds with proteins followed by phenol penetration into cells and cause precipitation and denaturation of 
proteins, thereby activating essential enzyme systems in bacterial cells (Hidayah et al., 2017).

\section{Antioxidant properties}

Antioxidant activity is showed in Table 4. It has been seen that probiotic drink based on Moringa oleifera has an antioxidant activity of approximately $70 \mathrm{GAE} / \mathrm{mL}$. Besides, it has total phenol between $0.22-0.24$ equivalent gallic acid $/ \mathrm{mL}$. The higher antioxidant activity and phenolic content was the product with an addition $7 \%$ skim milk powder. The antioxidant activity of functional drinks is influenced by the high content of vitamin $\mathrm{C}$ in moringa leaves. According to Werdhasari (2014), antioxidants from natural ingredients are obtained from active ingredients such as vitamin $C$, vitamin $E$, provitamin $A$, organosulfur, and flavonoids. The most nutritious moringa plant content is the antioxidants, especially in the leaves that contain high antioxidants such as vitamin $\mathrm{E}$ ( $\alpha$-tocopherol) $104 \mathrm{mg} / 100 \mathrm{~g}$ (Mubarak et al., 2017) vitamin C $203.1 \mathrm{mg} .100 \mathrm{~g}-1$ DM (Lalas et al., 2017), and vitamin A around $3.31 \mathrm{mg} / \mathrm{g}$ (Tahir et al., 2016).

Table 4. Antioxidant properties of probiotic drink based Moringa oleifera

\begin{tabular}{ccc}
\hline $\begin{array}{c}\text { Variation of } \\
\text { Skim Milk } \\
(\%)\end{array}$ & $\begin{array}{c}\text { Antioxidant Activity } \\
(\%)\end{array}$ & $\begin{array}{c}\text { Total Phenol mg } \\
\text { Equivalent Galic } \\
\text { Acid/mL Sample }\end{array}$ \\
\hline 0 & $72.53 \pm 1.21^{\mathrm{b}}$ & $0.2355 \pm 0.0013^{\mathrm{b}}$ \\
3 & $71.02 \pm 1.64^{\mathrm{b}}$ & $0.2374 \pm 0.0021^{\mathrm{bc}}$ \\
5 & $64.95 \pm 1.42^{\mathrm{a}}$ & $0.2266 \pm 0.0029^{\mathrm{a}}$ \\
7 & $75.18 \pm 1.45^{\mathrm{c}}$ & $0.2410 \pm 0.0054^{\mathrm{c}}$ \\
\hline
\end{tabular}

The difference in antioxidant activity and total phenol content is due to antioxidant compounds, including polyphenols found in moringa leaves. The total phenol in this functional drink ranges from 0.22 to $0.24 \mathrm{mg} / \mathrm{mL}$. The results of the study of Ramdhan and Aminah (2014) stated that the content of phenol fresh moringa leaves was $5.4 \mathrm{mg} / \mathrm{mL}$. Processing methods affect antioxidant content such as polyphenols in vegetables, which can increase or decrease. It is mainly due to the softening or denaturation of plant tissue or cellular disruption and separation of some phenolic compounds from cellular structures when processing vegetables. The decrease in total phenol levels is affected by the process's stages from fresh ingredients, extraction, dilution, and fermentation (Ramdhan and Aminah, 2014).

\section{CONCLUSION}

The research found that skim milk powders' addition significantly affects the product's color; it becomes lighter, greener, and more yellow $(P<0.05)$. The probiotic drink juices with supplementation of $7 \%$ skim milk powder had the highest protein content (2.65\%) and already fulfilled BSN (2009) for fermentation milk beverage. The higher the concentration of skim milk, the higher the $\mathrm{pH}$ and lactic acid content. Total viable probiotic among the treatment was not significantly different. The addition of $7 \%$ skims milk powder resulted in the highest protein content, antibacterial activity, phenolic content, and antioxidant activity. The probiotics drink based on moringa leaves juices has the potential to be developed as a functional drink.

\section{ACKNOWLEDGEMENT}

The author would like to extend their sincere gratitude to the Ministry of Research, Technology and Higher Education of the Republic of Indonesia to fund this research and the Research Center for Appropriate Technology, Indonesian Institute of Sciences for the facilities to conduct this research.

\section{REFERENCES}

Agustina W, Khoerunisa F, Rahman T, Ratnawati L. 2019. Karakterisasi dan pengujian akivitas antimikroba minuman probiotik antanan (Centella asiatica L.). J Riset Teknol Industri 13: 88-98. DOI: 10.26578/jrti.v13i1.5016.

Amara AA, Shibl A. 2015. Role of Probiotics in health improvement, infection control and disease treatment and management. Saudi Pharm J 23: 107-114. DOI: 10.1016/j.jsps.2013. 07.001.

Aminah S, Ramdhan T, Yanis M. 2015. Kandungan nutrisi dan sifat fungsional tanaman kelor (Moringa oleifera). Bul Pertanian Perkotaan 5: 35-44.

[AOAC] Association of Official Analytical Chemist. 2004. Official Methods of Analysis, $15^{\text {th }}$ Edition. Association of Official Analytical Chemist, Virginia.

Australia New Zealand Food Standar. 2007. Standard 2.5.3 Fermented Milk Products. Federal Register of Legislation, Australia.

Balouiri M, Sadiki M, Ibnsouda SK. 2016. Methods for in vitro evaluating antimicrobial activity - a review. J Pharm Anal 6: 71-79. DOI: 10.1016/j. jpha.2015.11.005.

Bruzantin FP, Daniel JLP, da Silva PPM, Spoto MHF. 2016. Physicochemical and sensory characteristics of fat-free goat milk yogurt with added stabilizers and skim milk powder fortification. J Dairy Sci 99: 3316-3324. DOI: 10.316 8/jds.2015-10327. 
[BSN] Badan Standardisasi Nasional. 2009. SNI 2981: 2009 Yogurt. Badan Standardisasi Nasional, Jakarta.

[BSN] Badan Standardisasi Nasional. 2009. SNI 7552: 2009 Minuman Susu Fermentasi Berperisa. Badan Standardisasi Nasional, Jakarta.

Desnilasari D, Kumalasari R. 2017. Characteristic of fermented drink from whey cheese with addition of mango (Mangifera $x$ odorata) Juice. IOP Conf Ser Earth Environ Sci 73: 1-6. The International Conference on Natural Products and Bioresource Science 2017 (ICONPROBIOS 2017) 23-24 October 2017, Balai Kartini Convention Center, Jakarta, Indonesia. DOI: 10.1088/1755-1315/101/1/012024.

Ferreira PMP, Farias DF, Oliveira JT de A, Carvalho A de FU. 2008. Moringa oleifera: Bioactive compounds and nutritional potential. Rev Nutr 21: 431-437. DOI: 10.1590/S1415-5273200800 0400007.

Gezginc Y, Topcal F, Comertpay S, Akyol I. 2015. Quantitative analysis of the lactic acid and acetaldehyde produced by Streptococcus thermophilus and Lactobacillus bulgaricus strains isolated from traditional Turkish yogurts using HPLC. J Dairy Sci 98: 1426-1434. DOI: 10.31 68/jds.2014-8447.

Gopalakrishnan L, Doriya K, Kumar DS. 2016. Moringa oleifera: A review on nutritive importance and its medicinal application. Food Sci Hum Wellness 5: 49-56. DOI: 10.1016/j.fshw. 2016.04.001.

He M, Shi B. 2017. Gut microbiota as a potential target of metabolic syndrome: The role of probiotics and prebiotics. Cell Biosci 7: 1-14. DOI: 10.1186/s13578-017-0183-1.

Hidayah N, Mustikaningtyas D, Bintari SH. 2017. Aktivitas antibakteri infusa simplisia sargassum muticum terhadap pertumbuhan Staphylococcus aureus. Life Sci 6: 49-54.

Insyiroh U, Budi S, Abduh M. 2014. Nilai pH, keasaman, citarasa, dan kesukaan susu fermentasi dengan penambahan ekstrak buah nanas asam. J Aplikasi Teknol Pangan 3: 114-116.

Khotimah K, Kusnadi J. 2014. Aktivitas antibakteri minuman probiotik sari kurma (Phoenix dactilyfera L.) menggunakan Lactobacillus plantarum dan Lactobacillus casei. J Pangan Agroind 2: 110-120.

Lalas S, Athanasiadis V, Karageorgou I, Batra G, Nanos GD, Makris DP. 2017. Nutritional characterization of leaves and herbal tea of Moringa oleifera cultivated in Greece. J Herbs, Spices Med Plants 23: 320-333. DOI: 10.1080/ 10496475.2017.1334163.
Martinez K, Talavera G, Alonso J. 2017. Effect of three drying methods on antioxidant efficiency and vitamin C content of Moringa oleifera leaf extract. Int J Chem Mater Eng 11: 754-757. DOI: 10.1999/1307-6892/10008255.

Mawouma S, Ponka R, Mbofung CM. 2017. Acceptability and solubility of iron and zinc contents of modified Moringa oleifera sauces consumed in the Far-north region of Cameroon. Food Sci Nutr 5: 344-348. DOI: 10.1002/ fsn3.398.

Melo V, Vargas N, Quirino T, Calvo CMC. 2013. Moringa oleifera $\mathrm{L}$. an underutilized tree with macronutrients for human health. Emirates $\mathrm{J}$ Food Agric 25: 785-789. DOI: 10.9755/ejfa. v25i10.17003.

Moyo B, Masika PJ, Hugo A, Muchenje V. 2011. Nutritional characterization of moringa (Moringa oleifera Lam.) leaves. Afr J Biotechnol 10: 12925-12933. DOI: 10.5897/AJB10.1599.

Mubarak K, Natsir H, Wahab AW, Satrimafitrah P. 2017. Analysis of $\alpha$-tokopherol (Vitamin E) extracted from moringa leaves (Moringa oleifera Lam) collected from seashore and highland areas and its potencyal as antioxidant. Kovalen: J Riset Kimia 3: 78-88. DOI: 10.22487/j2477 5398.2017.v3.i1.8236.

Olusanya RN, Kolanisi U, Onselen AV, Ngobese NZ, Siwela M. 2019. Nutritional composition and consumer acceptability of Moringa oleifera leaf powder (MOLP)-supplemented mahewu. S Afr J Bot 129: 175-180. DOI: 10.1016/j.sajb.2019. 04.022.

Pato U, Yusuf $Y$, Rossi E, Yunaira R, Githasari T. 2017. Quality of probiotic fermented milk using Lactobacillus casei subsp. casei R-68 as a starter with the variation of skim milk and sucrose. Int J Agric Technol 13: 37-46.

Rahmawati E. 2015. Kadar Protein, pH dan Jumlah Bakteri Asam Laktat Yogurt Susu Sapi dengan Variasi Penambahan Sari Daun Kelor dan Lama Fermentasi yang Berbeda. [Disertasi]. Surakarta: Fakultas Keguruan dan IImu Pendidikan, Universitas Muhammadiyah.

Ramdhan T, Aminah S. 2014. Pengaruh pemasakan terhadap kandungan antioksidan sayuran. Bul Pertanian Perkotaan 4: 7-13.

Sankhyan N, Sharma A, Seth CA, Chauhan A, Kulshrestha S. 2013. Determination and comparison of vitamin C content from Moringa oleifera by different methods. Int J Agric Sci Res 3: 67-70. 
Shao Y, Xu F, Sun X, Bao J, Beta T. 2014. Identification and quantification of phenolic acids and anthocyanins as antioxidants in bran, embryo and endosperm of white, red and black rice kernels (Oryza sativa L.). J Cereal Sci 59: 211-218. DOI: 10.1016/j.jcs.2014.01.004.

Sompong R, Siebenhandl-ehn S, Linsberger-martin G, Berghofer E. 2011. Physicochemical and antioxidative properties of red and black rice varieties from Thailand, China and Sri Lanka. Food Chem 124: 132-140. DOI: 10.1016/ j.foodchem.2010.05.115.

Tahir M, Hikmah N, Rahmawati R. 2016. Analisis kandungan vitamin $C$ dan $\beta$ - karoten dalam daun kelor (Moringa oleifra Lam.) dengan metode spektrofotometri UV-Vis. J Fitofarmaka Indonesia 3: 135-140. DOI: 10.33096/jffi.v3i1. 173.
Vanajakshi V, Vijayendra SVN, Varadaraj MC, Venkateswaran G, Agrawal R. 2015. Optimization of a probiotic beverage based on moringa leaves and beetroot. LWT-Food Sci Technol 63: 1268-1273. DOI: 10.1016/j.Iwt.2015.04.023.

Werdhasari A. 2014. Peran antioksidan bagi kesehatan. J Biotek Medisiana Indonesia 3: 59-68.

Yuliana N, Noviyeziana T, Sutikno S. 2017. Karakteristik minuman laktat sari buah durian Lay (Durio kutejensis) yang disuplementasi dengan kultur lactobacillus selama penyimpanan pada suhu rendah. Agritech 36: 424-432. DOI: 10. 22146/agritech.16766.

Zhang $\mathrm{T}$, Jeong $\mathrm{CH}$, Cheng WN, Bae $\mathrm{H}$, Seo $\mathrm{HG}$, Petriello MC, Han SG. 2019. Moringa extract enhances the fermentative, textural, and bioactive properties of yogurt. LWT 101: 276-284. DOI: 10.1016/j.Iwt.2018.11.010. 